The Geneva Papers on Risk and Insurance, 14 (No. 52, July 1989), 279-291

\title{
16th Annual Report on the Activities of the Geneva Association
}

\author{
for the period June 1, 1988 to May 31, 1989
}

\section{Overview of the key research issues}

It is important to remember that the Geneva Association was founded in 1973. Sixteen years later the intuition of the founding fathers of the "International Association for the Study of Insurance Economics" appears particularly farsighted.

In fact, 1973 was the year when the period of extraordinary overall economic growth that had started right after World War Two (at an average rate for all industrialized countries of $6 \%$ p. a.) came to a definitive halt: the oil crisis was the first dramatic signal of a period of profound economic change and adjustment. Since then, economic development has slowed down to an average rate of 2 to $3 \%$, which in fact had been the overall rate of development for the two centuries since the start of the Industrial Revolution. The reasons for the exceptional growth between 1947 and 1973 were described in two books by the two main collaborators of the Geneva Association. ${ }^{1}$

1973 was also the start of a new era in the long history of the insurance business. At the outset we maintained that, because of important changes in the overall economy, insurance was now emerging as a key economic factor (from its secondary role during the period of the industrial revolution) fully integrated into a comprehensive strategy for economic development. ${ }^{2}$ The central thesis was that the management of vulnerability (i.e. of pure and insurable risks) had become a fundamental part of economic management strategy, both at the macro and micro levels, because of the growing complexity of the economy and an increasing use of higher levels of sophisticated technology.

This observation led the Geneva Association to monitor from the very beginning the birth and rise of risk management functions within industrial companies and to accomplish

\footnotetext{
${ }^{1}$ See the "Diminishing Returns of Technology" by Orio Giarini and Henri Loubergé, Pergamon Press, Oxford 1978 and "Dialogue on Wealth and Welfare-Report to the Club of Rome", Pergamon Press, Oxford, 1980.

2 The first explicit document in this sense was the "Lettre d'Information" No. 19 of the Geneva Association of March 24, 1975 entitled "Economics, Technology and Vulnerability (L'Economie du Risque et de l'Assurance)". This text was republished in the Geneva Papers No. 6, October 1977.
} 
in its earlier years the first general survey in Europe of risk management practices in industry. ${ }^{3}$

The perception of risk management not simply as an occasional activity but as confirmation of the hypothesis that in the new economic situation the management of pure risk had finally become strategically as important as the management of commercial risk, was the key reason for the healthy development of our research programme on industrial risk and for our enhanced credibility with the industrial partners. The increased complexity of risk management problems in most economic sectors was largely responsible both for increasing uncertainty in the economy and for the continuously and simultaneously rising importance of the insurance business in all sectors. This was clearly a fundamental reversal of the traditional situation during the classical industrial revolution when any slow-down in economic activity triggered an even bigger slow-down in the acquisition of insurance policies, as they were considered a secondary type of economic activity. In the new situation, where vulnerability issues have become a clear priority, the slow-down in economic development means in fact a more than proportional growth of insurance business. This was probably the single most specific and successful prediction we had made at the time of the foundation of the Geneva Association.

Current studies on risk management and industrial risks are focusing on the problems related to the future of the liability markets. In a service economy, where the value of performance is more significant than the value of material products, it is obvious that the question of liability, arising from the specific demand of consumers for good performance by both people and material products, becomes an important issue.

Our understanding, right at the beginning, that the economic crisis which started in 1973 differed radically from preceding ones - a fact that eluded the majority of economists (who for several years went on contending that it was part of the normal business cycle) led us to move our enquiries in a new direction. Already in 1973, we were convinced that we were about to witness a general slow-down in the expansion rate of the economy (from $6 \%$ p.a. to $2-3 \%$ p.a.). It was then obvious that the long-term obligations of retirement schemes in the public social security systems would sooner or later falter and the authorities would be obliged to give up some of the generous goals set at that time. In other words, it was important to verify how far States or Governments could implement their social

\footnotetext{
3 This report was first published in issue No. 2 of the GENEVA PAPERS (August 1976). This issue had to be reprinted in 1977 because of a large demand following its use as a basic document for the first conference of the European Association of Risk Managers in Industry held in Bruges. Other papers on similar themes were presented by the Geneva Association to the inaugural conferences of other new Associations such as the Brussels-based European Association of Reliability Engineers.

The Geneva Association also started a series of studies of specific sectors of vulnerability in industrial development: the first concerned the losses resulting from the utilization of computers (published in the Geneva Papers No. 3, Oct. 1976). A pioneer in this area of research, this study has stimulated the setting-up of specialized computer insurance programs in several insurance companies, which have become a success. Studies on the vulnerability of container systems, liquified natural gas storage systems, aerospace, etc. have since followed.
} 
security schemes and, once these limits were identified, to determine to what extent private schemes could complement the financial security of households and individuals.

When the Geneva Association launched its first studies in this direction in key European countries (Germany, Great-Britain, France and Italy), the analyses of social security on the one hand and of private life insurance and pension schemes on the other were rarely considered together. A study in France by Denis Kessler and Dominique Strauss-Kahn was particularly successful and was later published as a book. ${ }^{4}$ Today, the picture has totally changed and the market for all forms of savings and pension schemes has become almost explosive.

As the role of the Geneva Association is that of an explorer, it is clear that as soon as our studies began to show that new important markets were emerging, our activities had to be redirected towards issues connected with new markets which had a chance to develop further on in the future. Our research is normally based on the principle of being "two or three years" too early. These new directions are described in the following paragraphs of this report: studies in the sectors related to savings and life insurance have now given way essentially to work on "The Four Pillars".5

During the first seven to eight years of our activity, which took off at the time of the 1973 crisis, the mood of governments, economists and most actors on the economic scene remained rather pessimistic. The fact that an average economic growth of $6 \%$ p.a. could no longer be achieved, created a situation where economic opinion continued to speak of crisis, forgetting that the period of high growth after World War Two had been the exception and that economic growth of $2-3 \%$ was very much in line with the traditional performance of the industrial revolution from its start in the 18th century. On the one hand, there were the "optimists" who just waited for the recovery of economic growth at the "normal" rate of $6 \%$. And on the other, there were those who, given the emerging problems of environmental and pollution management, proposed that henceforth economic growth of any kind would be unacceptable.

It was at this point that the hypothesis surfaced that the crisis which had started in 1973 was due to a fundamental and far-reaching change in the mechanism of economic wealth production. This hypothesis was instrumental in shifting the focus of our attention from a discussion of why things were going wrong, to investing more and more time in understanding the fresh potential and possibilities of the new situation. The emergent thinking, which was to gain ground during the late seventies and early eighties, held that we were witnessing the transition from an economy where resources (i.e. costs) are absorbed essentially by the manufacturing processes into one in which - because of ever-increasing levels of technology - good and efficient production and distribution are conditioned primarily by the growing need for adequate service functions (research and development, financing, quality control, maintenance, storage, distribution, vulnerability management, recycling, etc.). This means that the economy has entered a "service" phase of development where even within the production sector, services account for at least $70 \%$ of costs and employment. Services are no longer antagonistic to manufacturing production. They are on the

\footnotetext{
${ }^{4}$ Denis Kessler and Dominique Strauss-Kahn, "L'épargne et la retraite", Economica Paris, 1982.

5 The overall research programme in this sector is described in our information letter "The Four Pillars", which is distributed in about 800 copies around the world.
} 
contrary an indication that manufacturing has achieved a higher level of development where economic costs are increasingly related to the service functions necessary to make all material products available and usable. In economic terms, service functions at all stages of production from "cradle to grave", i. e. from product design to the recycling of waste, are now the key economic factor in the production function.

This means that the service economy not only encompasses the growth of the traditional services sector (which makes increasing use of industrial systems of production) but that the essential phenomenon is the growing strategic importance of service functions within all economic activities.

A new challenge was thus facing the Geneva Association. It was clear that within the framework of an economy seen essentially as an industrial manufacturing system, the function of services, and in particular of insurance, could only be considered secondary, even if of some importance. However, if the modern economy could really be perceived as a "service economy", the economic role of services and in particular of insurance, would be fully integrated and appreciated as essential for the proper understanding of any economic situation and development. ${ }^{6}$

The positioning of insurance activities within a vision of the modern economy as a service economy became therefore a challenging research hypothesis for the Geneva Association. ${ }^{7}$ It is within these key ideas that a profound coherence can be found within the varied activities of the Geneva Association.

In the context of the new service economy, it is important to re-analyse the economic conditions of competition, economy of scale, productivity, efficiency and performance of insurance companies. It is within this framework that new specific research under the responsibility of Professor Kessler has just started.

In the following chapters, we examine the specific work done during the last twelve months: each initiative, be it a research study, a seminar or a lecture can be seen as a single branch that forms part of one large tree.

\section{Research Work}

\subsection{Studies on the Four Pillars}

As we have recalled in the first part of this report, the Geneva Association has been a pioneer in launching about ten years ago some of the earliest studies in Europe, on the limits of social security and government old-age pensions schemes and on the complementary role of private insurance. Today, this theme has become central to the development of insurance in most countries.

\footnotetext{
${ }^{6}$ This concept was examined in detail in the article "The cultural foundation of the brand image of insurance" published in the Geneva Papers No. 48, July 1988, page 229.

${ }^{7}$ The idea of describing the contemporary economy as a service economy has given birth to one of our bulletins, called "PROGRES" (Programme of Research on the Economics of Services) which collects and diffuses around the world information on research into this approach. The initiative has proved rather successful as the bulletin is now requested by about 1800 people around the world. The circulation of "PROGRES" has also contributed to the creation of a club of people interested in studying the service economy, called the "SERVICES WORLD FORUM", as also to the presentation of the first course in the economics of services at the Graduate Institute of European Studies of the University of Geneva.
} 
The Geneva Association is now developing a research programme in another direction: we are examining the current profound changes in demographic structure as well as the growing development of part-time work for those over 60 years of age. Part-time work can be considered a "fourth pillar" for the older population, in their attempt to achieve a better balanced level of financial security as well as more satisfying integration as active members of society. It is clear that the four pillars (state pensions, private schemes, direct savings and income from part-time work) will remain interdependent. Both practical initiatives and changes in legislations (which are beginning to occur in particular in the Northern European countries) are leading to interesting new approaches in this field. The problem will become very acute at the end of the century when the "baby-boom" starts substantially to increase the percentage of people over 60 within the total population in Europe and in the United States. The present baby-boom in developing countries elsewhere in the world will obviously give rise to the same type of problems in two or three decades time on an even larger scale.

- The preliminary study in Germany, supervised by Mr. Laskowski and undertaken by Mr. Jürgen Kruse and Mr. Werner Steinjan, was finished in 1988 and published in German as a book by the Verlag Versicherungswirtschaft e. V., Karlsruhe. An English translation of the study was published as No. 131 in the series Etudes \& Dossiers.

- A preliminary study based on interviews done in the UK, France, Germany and Switzerland by Walter Stahel as also an initial survey supervised by Dr. Menconi in Italy were published in the Etudes \& Dossiers No. 124. This publication also contains a Four Pillars scenario for the year 2013 by Orio Giarini : this text was used as a basis for discussion at the U.S. Actuarial Conference, held in Chicago in November 1988.

- A first report on "the Four Pillars" by Denis Kessler is now ready and in the process of being published in the series Etudes \& Dossiers.

- In the United Kingdom, the overall Four Pillars project and its strategic implications, with reference to the study done in Germany, are being researched with a major contribution by Professor Antony Ratcliff. A second study, focusing on the possibilities of parttime jobs for retired people is being undertaken by Dr. Amin Rajan with the support of the Association of British Insurers. It is hoped that the insurance industry will be in a position to benefit directly from this study.

- Documentation work on these issues is done by Geneviève Reday-Mulvey, with contributions from other members of the research team. This has resulted in the publication of two issues of "The Four Pillars Bulletin", an important tool for the entire research programme.

- A coordination seminar for the various members of the team, including representatives from other countries, was organized in Paris on June 8 and 9, 1989, by Denis Kessler.

- In addition, this research subject was one of the themes discussed at the last General Assembly of the Geneva Association in The Hague, on June 13, 1988, as well as at the 3rd International Conference on Strategic Issues for Insurance held in London on October 20, 1988.

- A research meeting was also organized in Rome, on April 26, 1989, with the Advisory Council C.I.R.S.A. (Italian Research Centre for Insurance), in order to prepare a study programme on the Four Pillars for 1989-90. 


\subsection{The Economic Roots of Competition, Economy of Scale, Efficiency and Performance of}

Insurance Companies

- It has for long been suggested by members of the Geneva Association that a fundamental economic study should be started on the question of competition and performance of insurance in Europe. The matter is as delicate as it is important. We have spent several months with Professor Kessler in defining how such a study could start. The programme is now under way with the help of Professor Pestieau of the University of Liège. A small team of contributors will be built up as the programme proceeds. Initially research will look at the French speaking countries, with contributions from insurance companies, CAPA (Comité d'Action pour la Productivité dans l'Assurance), and the French Federation of Insurance Companies. A first meeting took place on January 17, 1989, when a specific research programme was defined. At a second meeting on March 8, a series of research documents related to the economic analysis of insurance in France (market structures, efficiency and profitability) was established.

\subsection{Study on Comparative Procedures in the Liability Sector}

- The first report of the UK, Germany and Holland was published in the Etudes \& Dossiers as No. 127, October 1988.

- A parallel study done in the United States and financed by the Alliance of American Insurers is now available in draft form.

- These preliminary studies were the reference point for a meeting organized at the Swiss Re in Zürich, on December 8-9 1988, in order to analyse the results of the first part of the research work and decide on the possibility of developing it. This study is being closely followed by our President, Prof. Reimer Schmidt, and also benefits from the collaboration of various experts, in particular, Mr. Szöllösy of the Swiss Re and Mr. Martin Albaum, Head of the Strategic Planning of the Prudential Corporation in the USA.

- Another meeting, followed by the Deputy Secretary General, Mr. Walter Stahel, and organized by Prof. Pfennigstorf, took place in Hamburg on May 18, 1989. Its purpose was to identify the next steps for research in this area.

- Further input for this programme was provided by the second panel of the General Assembly of the Geneva Association in Paris on June 6,1989. Thereafter we expect to be able to define more precisely the future direction of this line of research.

\subsection{Studies on Risk Management, Environmental Issues and Insurability}

- The issues, presented and discussed at the Wharton School last May, were discussed again at the London meeting on October 21, 1988, with contributions by Professor Kunreuther of the Wharton School, Mr. Rosenthal of the Rohm \& Haas Chemical Company (Philadelphia), Dr. Spühler of the Swiss Re and Mr. Schroeder of the Zurich Insurance Co. The main papers were published in the Geneva Papers No. 51 (April 1989).

- These issues plus the studies and experience of Walter Stahel on the question of durability and waste management, prompted the organization of an International Conference on January 16-17, 1989, (financed by the Migros Foundation in Rüschlikon and held at the 
Swiss Federal Institute of Technology in Zurich). Among the contributors and organizers were several insurance (as well as chemical) companies. The texts will be published by Elsevier as a book later this year.

\subsection{2 - Strategic Issues for European Insurance}

- A questionnaire prepared by Prof. Reimer Schmidt and Prof. Dieter Farny was distributed to all our members in French, English and German. The results of this questionnaire on 1992 and the main strategic issues for insurance were presented by the authors at the Annual Conference of German Insurers in March, 1989.

- The strategies of insurance companies in Europe were discussed at the Conference on Strategic Issues in London on October 21, 1988 by Mr. Michael Butt, Dr. Carlo Acutis, Mr. Steve Schleisman and Mr. Ruy de Carvalho.

- Also at the above conference, were discussed the following strategic issues: the freedom of services and capital movements with reference to the development of the ECU; the problems related to the harmonization of fiscal systems in the European Community (on the basis of studies prepared by Peat Marwick). The papers were published in the Etudes \& Dossiers No. 132 and 133.

\subsection{Study on the Service Economy}

- The notion of the service economy as a more appropriate way of describing current economic reality is gaining ground and makes for a clearer definition of the economic role of insurance. The key reference for our promotional and research activities in this area is the Newsletter "PROGRES". Furthermore, Orio Giarini and Jean Rémy Roulet have edited two books with the support of the Graduate Institute of European Studies of the University of Geneva: the first one (in French) on "Europe and the New Service Economy" (published by Presses Universitaires de France, Paris) and a second published directly by the Institute (in French) on "Switzerland and the Common Market Facing the Liberalization of Services".

\subsection{Teaching of Risk and Insurance Economics}

- A programme directed by Professor Kennedy of the City University Business School in London in this area is under way. The new version of this study will be computerized and can thus be continuously updated.

\subsection{Study on "Crime and Insurance"}

- This study has finally started in Germany, under the responsibility of Prof. G. W. Wittkämper, Director of the Political Science Institute of the "Westfälische WilhelmsUniversität". The programme of research is being followed by our President and the Vice-Secretary General, Dr. H.-J. Welzel, and supported by the German Insurance Federation.

\section{Organization of Conferences and Seminars}

3.1 The 15th General Assembly of the Geneva Association took place in The Hague on June 13-14, 1988. Two panels were organized: One on "AIDS and Insurance" with the 
participation of the World Health Organization, the other on "The Four Pillars". The key papers from these panels have been published and circulated in the October issue of the Geneva Papers (No. 49).

3.2 The Twelfth Annual Lecture of the Geneva Association was organized in Paris on June 29, 1988 with the collaboration of Prof. Thomas Merton of Harvard University, one of the best known economists on financial matters. His lecture was complemented by contributions from Sir Brian Corby (Prudential, London) and Mr. Jean Dromer (UAP, Paris). Our Annual Lecture was also read to the International Financial Conference, organized simultaneously by HEC (Hautes Etudes Commerciales) of Paris and the Chamber of Commerce of Paris which attracted an audience of about 300 people. The texts of the lecture and of the discussions are published in the Geneva Papers No. 52, July.

The Thirteenth Annual Lecture of the Geneva Association was organized with Prof. Ilya Progogine, Nobel Prize, on the subject "Risk in Science and Society" and at the occasion of the General Assembly of the Geneva Association on June 5, 1989 in Paris under the chairmanship of Prof. Raymond Barre, former President of the Geneva Association.

The Fourteenth Annual Lecture will take place in 1990 with the collaboration of Prof. W. J. Baumol, New York University, probably in London.

3.3 The Fifth Seminar of the Series "Risk and Society" on "Genetic Risks" was organized within the framework of the International Conference on Strategic Issues in London, on October 19, 1988. Contributors were representatives from the International Science Policy Foundation, as also from the medical and biological research and insurance sectors.

- The Sixth Meeting on Risk and Society was organized in London on January 13, 1989 on the subject of "Human Error and Insurance".

- The Seventh Meeting has taken place in London on June 9, 1989 on "New Perspectives of Oil Risks".

These meetings are organized in collaboration with the I.R.R.G. (Insurance and Reinsurance Research Group, London).

3.4 A new series of "Geneva Lectures" has been inaugurated by our President Prof. Reimer Schmidt. These lectures are reserved for our members as opportunities to speak in a foreign country. The first lecture of the series took place on October 28, 1988, at the Swiss Re in Zürich, on the subject of "Insurance in 1992 in Europe". A considerable audience was present on this occasion coming from Germany, Austria and Switzerland.

- The Second Geneva Lecture has been delivered in New York in June 1989, with the collaboration of Mr. Claude Bébéar.

3.5 An International Conference on Strategic Planning was organized in London on October 19-21, 1988. William Kent House in the West End was made available by Eagle Star for the occasion. A total of about 150 people participated at five sessions on 
different specific topics (Genetic Risks, the Four Pillars, Europe 1992: the Role of ECU and Fiscal Problems, Strategies of Insurance Companies, the Management of Hazardous Waste and the Insurance of Environmental Liabilities).

3.6 The Sixth International Seminar of More (Management of Risk in Engineering) took place in London on October 26-28, 1988. The role of this group is to enhance understanding among engineers of risk and insurance economics. This seminar was held in collaboration with the Trent Polytechnic in Nottingham and managed by Walter Stahel. The main papers will be published as a book later in 1989 .

3.7 The Fifteenth Annual Seminar of the European Group of Risk and Insurance Economists took place for the first time in Lisbon at the Universidade Nova on September 19-21, 1988. This successful meeting brought to light the availability of qualified economists interested in insurance problems in Portugal. The following seminars will take place : 1989 in Paris, 1990 in Vienna, 1991 in Geneva and 1992 in Brussels.

3.8 A first seminar exclusively devoted to the impact on insurance of the European Monetary System and to the private utilisation of ECUs was organized in Geneva on March $20-21,1989$. About 25 participants contributed to the analysis and discussion of this subject. A third of the participants came from banks in Switzerland, France, Italy and Belgium. Another third came from industry, industrial organizations (St. Gobain, Tabacofina, ESA) and international institutions (the European Communities and the European Investment Bank). The last third of participants was made up of insurers, reinsurers and financial research experts. The results of this debate will be published jointly by the Geneva Association and a financial magazine specializing in the ECU in Brussels.

- We also contributed to the organization of a small seminar on Switzerland and the European Monetary System at the Graduate Institute of European Studies on May $10,1989$.

- A third meeting on similar issues is being organized in London for November 15 , 1989 with the collaboration of Dr. Gerry Dickinson.

3.9 Fifth Seminar on Service Economics, Geneva, May 29-31, 1989. The Geneva Association organized this seminar, in conjunction with the Graduate Institute of European Studies of the University of Geneva and the Services World Forum. More than fifty participants from Europe, the United States, several Eastern European countries as well as representatives of several international institutions contributed to the three day programme.

3.10 We are also continuing our series of joint seminars with the European Law and Economics Association. The Third Seminar in collaboration with this Association has been organized at the University of Lund, Sweden, on August 28-30, 1989. The proceedings of the previous seminar are to be published in the October 1989 and January 1990 issues of the Geneva Papers. 


\section{Publications}

During this period the following have been published:

- The Geneva Papers on Risk and Insurance

- No. 48 (Risk and Society, The Discount Rate, Risk and Insurance Issues)

- No. 49 (The Four Pillars, AIDS and Other Insurance Issues)

- No. 50 (Essays in Insurance Economics)

- No. 51 (Management Waste Handling \& Pollution Risks)

- Les Etudes \& Dossiers:

- No. 123, June 1988

A Preliminary Survey of the Losses from the Utilization of Computer System Affecting the Insurance Industry in Europe up to the Year 2000.

- No. 124, July 1988 Enquiries and Preliminary Studies on the "Fourth Pillar".

- No.125, August 1988 Transition to Retirement: The Four Pillars, Documents and Texts from the Panel of the 15th General Assembly of the Geneva Association.

- No. 126, September 1988

AIDS and Insurance, Documents and Texts from the Panel of the 15th General Assembly of the Geneva Association.

- No. 127, October 1988

Comparative Costs and Procedures of Liability Claims, Preliminary Studies on the UK, F. R. of Germany and Holland.

- No. 128, November 1988

Risk Management and Insurance (Risk Management und Versicherungslehre), by Wolf-Rüdiger Heilmann, University of Karlsruhe/FRG.

- No. 129, December 1988

Insurance Economics Issues, Papers from the 15th Seminar of the European Group of Risk and Insurance Economists, Lisbon, September 19-21, 1988, Volume I.

- No. 130, January 1989

Insurance Economics Issues, Papers from 15th Seminar of the European Group of Risk and Insurance Economists, Lisbon, September 19-21, 1988, Volume II.

- No. 131, February 1989

Prolonged Lifetime Employment and a Flexible Transition from Labor Force Participation to Retirement in View of Future Requirements of the Labor Market and Old Age Pensions - A contribution to the discussion in the FRG.

- No. 132, March 1989

Papers from the Third International Seminar of the Geneva Association on Strategic Planning For Insurance, Volume I.

- No. 133, April 1989

Papers from the Third International Seminar of the Geneva Association on Strategic Planning for Insurance, Volume II.

- No. 134, May 1989

Papers from the International Conference on Industrial Risk Management on LifeCycle Engineering and Risk Management. 
- The Economists' Newsletter No. 23, 24

- The Four Pillars No. 6, 7

- The Risk Management Bulletin No. 6, 7

- PROGRES No. 9, 10, 11

- Lettre d'Information (Newsletter) No. 111, 112, 113

\section{Lectures given by the staff of the Geneva Association and participation to conferences}

- The Secretary General, Orio Giarini, has given the following lectures:

- On August 19, 1988 in Helsinki at the World Congress of Small Business on "Risk Management in the Service Economy".

- On August 15, 1988 at Karlstad University in Sweden for an International Symposium on Services on "The Management of Quality in the Service Economy".

- On September 7, 1988 at Monte Carlo (Rendez-vous de Septembre) on "An Economic View of Catastrophic Losses".

- On September 16, 1988 in Lugano for the American Insurance Group - Ticino Vita on "The Future of Insurance in the Service Economy".

- On October 3, 1988 in Berlin at an International Symposium of the German Institute for Economic Research on "The Management of Risk in the Service Economy".

- On October 26, 1988 in Paris at the 20th Anniversary Assembly of the Club of Rome on "The Management of Uncertainty in the New Service Economy".

- On December 2, 1988 in Halifax (Nova Scotia, Canada) on "The Importance of the Notion of the Service Economy and of Risk Management for the Research and Development of the Resources of the Oceans" (Conference organized by the Canadian Institute for the Development of the Ocean and the International Ocean Institute of Malta).

- On December 15, 1988 in Brussels on "The Management of Risk in the Service Economy" for the European Association of Risk Managers in Industry.

- On March 8, 1989 in Milan for the EURETA-FAST programme of the European Communities on "The Services Revolution : Towards a New Economy".

- On March 31, 1989 in Geneva for the Quakers United Nations Office on "Economic Indicators, Risk and Development".

- On April 4, 1989 in Utrecht/Holland, Seminar for Insurance Managers on "Risk Management and Insurance in the New Service Economy".

- On April 19, 1989 in Lugano/Switzerland (Chairman of the Panel for the International Congress on Quality Management by the European Center for Insurance Education and Training of St. Gall) on "Quality and Social Responsibility in the Service Industry".

- On April 26-28, 1989, University of Rome, Introductory Lectures to the Service Economy and the Management of Risk.

- On May 9, 1989 in Stockholm, Analysis of the Main Future Trends of the Economy and the Management of Risk for the International Conference of Reinsurance Management of the SKANDIA Reinsurance Group. 
- Walter Stahel, Deputy Secretary General, has taken part or spoken at the following meetings:

- Munich, October 13-14, 1988, "Mikro-Elektronik-Grundlagen und Perspektiven", organized by the Deutscher Verein für Versicherungs-Wirtschaft.

- Zurich, November 14-15, 1988, "Liability Trends in Europe and the US", organized by Management Centre Europe.

- Co-organizer of the meetings of MORE (London, October 26-28, 1988) and of the meeting on Comparative Liability Procedures (Schweizer Rück, December 8-9, 1988).

- Organization of the first Geneva Lecture of the Geneva Association in Zurich (October 28, 1988).

- Zürich, January 16-17, 1989, "Product-Life: The Overall Design”, organized by the Green Meadow Foundation, and the Swiss Federal Institute of Technology, Zurich; chaired the meeting on the second day.

- Amsterdam, March 2-3, 1989, "Safety and Reliability Objectives in High Technology and Industry", organized by IBC London; paper on "Insurability of risks, risk prevention and system design".

- Nürnberg, March 8-10, 1989, Jahrestagung 1989 des Deutschen Vereins für Versicherungswissenschaft.

- Düsseldorf, April 6-7, 1989, Tagung des Deutschen Vereins für Versicherungswissenschaft, Abteilung für Versicherungsmedizin.

- London, May 17-18, 1989, "Pollution, Environmental Impairment and Waste - Risk Management and Insurance Aspects".

- Basel, May 10, 1989, Jahrestagung 1989 des Schweizer Versicherungsverbandes.

- Hamburg, May 17-19, 1989, working meeting on the comparative liability project of the Geneva Association, organized by Prof. Pfennigstorf.

- Geneva, May 30, 1989, 5th Annual Seminar on the Service Economy, Services World Forum, paper on "Services, Risk and Product-Life Optimization".

- Geneva, May 30 - June 1, 1989, "Waste Minimization and Clean Technology" conference, organized by ISWA, Washington; plenary paper on "Man-Machine Interface of Durability and Waste Prevention : Risk Management and Product-Life Optimization".

- Mr. Denis Kessler, Deputy Secretary General, beyond his activity as Project Leader of our study on the Four Pillars, has also participated or given lectures at the following meetings :

- July 18-21, 1988, Cambridge, Centre for Economic Policy Research, Seminar on "The Social Economy of the Second Half of Life". He presented a paper on "Why is there Social Security?".

- September 17-21, 1988, Sendai City (Japan), IUSSP, Seminar on The Family, the Market and the State in Ageing Societies. Paper on "Public and Private Intergenerational Transfers Within and Outside".

- October 4-5, 1988, Paris, Seminar organized by FUTURIBLES on The Ageing Demographic Structure. Paper presented on "The Four Pillars: Transition to Retirement". 
- October 13, 1988, Paris, Conference of the Society of Actuaries. Presentation of a paper on "The Principle of a Reform of the Fiscal Law with Regard to Savings and Insurance".

- October 23-26, 1988, Sevilla, Congress of EFMA on "The Trend to Disintermediation". Paper presented on "Is Disintermediation Unavoidable?".

- October 31, 1988, London, Seventh International Retail Banking Conference. Paper presented on "Quality in the Financial Services".

- November 23-24, 1988, Madrid, International Conference of CAPA for Insurance Companies. Paper presented on "The European Market: Stability of Disruption in the Market Shares".

- 10th French-British Congress "Population Economics", London, January 19-20, 1989, paper presented on "But why is there Social Security?".

- March 16-17, 1989, Brussels, De Vlerick School of Management: Globalisation and Financial Services Revolution. Paper presented on "Le Grand Marché Européen: Stabilité ou bouleversement des parts de marché ?".

- March 20, 1989, Paris - Journées Scientifiques UAP. Chairman of the session on "Large Technological and Biological Risks".

- April 24, 1989, Paris, French Bankers Association. Conference on "The Future Relations Between Banks and Insurance".

Mr. Denis Kessler has contributed to these seminars which are of relevance to our research programme on the Four Pillars both as Deputy Secretary of the Geneva Association and as Director of the FREF (Fondation pour la Recherche Economique et Financière, Paris).

Mr. S.P. L. Kennedy, Vice Secretary General, has participated at the following meetings:

- June 1989 - AFIM Conference on Information Science (Toulouse - Ajaccio, France).

- World Fire Statistics Centre: various meetings to set up and maintain a computer database system under Tom Wilmot.

In addition, Mrs Geneviève Reday-Mulvey, who is collaborating to the research on the Four Pillars, has participated and contributed for the Geneva Association to the following conferences:

- September 20-21, 1988, Geneva: World Congress of the ISSA (International Social Security Association) on "How to Combine Part-Time Jobs with Adequate Social Protection".

- September 22-23, 1988, Dijon (France) : 8th Seminar of Social Issues in the Economy. 